\title{
Karakteristik Air Lindi (Leachate) di Tempat Pembuangan Akhir Sampah Air Dingin Kota Padang
}

\author{
Resti Nanda Sari*, Afdal \\ Laboratorium Fisika Bumi, Jurusan Fisika, FMIPA, Universitas Andalas \\ Kampus Unand, Limau Manis, Padang, 25163 \\ *restinanda41@gmail.com
}

\begin{abstract}
ABSTRAK
Telah dilakukan penelitian untuk mengetahui karakteristik air lindi di Tempat Pembuangan Akhir (TPA) sampah Air Dingin Kota Padang. Pengambilan sampel air lindi dilakukan pada 6 titik lokasi, yaitu sebelum masuk kolam kendali, di kolam kendali, setelah keluar dari kolam kendali dan sungai. Karakteristik air lindi ditentukan dari beberapa parameter yaitu Total Dissolved Solid (TDS), konduktivitas listrik, pH, suhu, Chemical Oxygen Demand (COD), Biology Oxygen Demand (BOD) dan kandungan logam berat. Air lindi pada TPA memiliki nilai COD dan BOD serta kandungan logam berat $\mathrm{Pb}$ yang cukup tinggi dan telah melebihi nilai baku mutu pada beberapa titik tertentu (sebelum kolam, di dalam kolam dan setelah keluar dari kolam kendali). Untuk parameter suhu dan kandungan logam berat $\mathrm{Cu}$ dan Fe nilainya masih berada jauh di bawah baku mutu untuk semua titik sampel. Nilai parameter air lindi antara bak kendali berfluktuasi, dan ada yang justru jadi lebih tinggi setelah melewati proses pada kolam kendali seperti pada parameter konduktivitas listrik, TDS, pH dan kandungan logam berat $\mathrm{Pb}, \mathrm{Cu}$ dan Fe. Dari hasil tersebut maka dapat diketahui bahwa fungsi kolam kendali air lindi yang ada di TPA Air Dingin masih kurang efektif.

Kata kunci : TPA Air Dingin ,lindi, konduktivitas listrik, TDS, pH, logam berat.
\end{abstract}

\section{ABSTRACT}

The characteristics of leachate at Air Dingin Landfill in Padang have been investigated. Sample of leachate are collected at 6 points i.e. before entering the control pond, inside the control pond, after passing the control pond and at the river. Characteristics of leachate are determined by Total Dissolved Solid (TDS), electrical conductivity, pH, temperature, Chemical Oxygen Demand (COD), Biology Oxygen Demand (BOD) and heavy metal content. The values of the COD and Pb content at some particular point (before entering the control pond, inside the control pond, after passing the control pond) are higher than the Indonesian Standard for Leachate. On the other hand, the temperature, Fe and $\mathrm{Cu}$ contents for all sample points are lower than the standard. The parameter value of electrical conductivity, TDS, $\mathrm{pH}$ and $\mathrm{Pb}, \mathrm{Cu}$ and $\mathrm{Fe}$ contents fluctuate among control ponds, but the values after passing the control pond are higher than those before entering the control pond. Thus, the function of control ponds at the landfill does not work effectively.

Keywords: Air Dingin landfill, leachate, electric conductivity, Total Dissolved Solid, heavy metals.

\section{PENDAHULUAN}

Lindi (leachate) adalah cairan yang merembes melalui tumpukan sampah dengan membawa materi terlarut atau tersuspensi terutama hasil proses dekomposisi materi sampah (Damanhuri, 2010). Lindi dapat meresap ke dalam tanah yang menyebabkan pencemaran tanah dan air tanah secara langsung karena dalam lindi terdapat berbagai senyawa kimia organik dan anorganik serta sejumlah pathogen (Susanto, 2004). Untuk menanggulangi permasalahan lindi diperlukan upaya pengolahan lindi di lokasi TPA (Tempat Pembuangan Akhir).

TPA menjadi tempat penampungan berbagai macam sampah sehingga lindi mengandung berbagai jenis bahan pencemar yang berpotensi mengganggu lingkungan dan kesehatan manusia. Air lindi dapat merembes ke dalam tanah, ataupun mengalir di permukaan tanah dan bermuara pada aliran air sungai. Setiap TPA memiliki karakteristik air lindi yang berbeda tergantung dari proses yang terjadi di dalam landfill, yang meliputi proses fisika, kimia dan biologis. Al-Wabel dkk. (2011) yang melakukan penelitian mengenai karakteristik lindi di TPA di Kota Riyadh, Saudi Arabia menemukan bahwa lindi di lokasi tersebut mengandung Chemical Oxygen Demand (COD), Biology Oxygen Demand (BOD), Electrical Conductivity (EC), Total Suspended Solid (TSS) dengan konsentrasi yang tinggi tetapi memiliki nilai $\mathrm{pH}$ yang rendah. Selain itu, lindi di TPA Kota Riyadh mengandung Fe, Mn, Mo, Ni, Cr, Zn dan Cu. Zubair dkk. (2012), menemukan bahwa hasil pengujian sampel air lindi di TPA Maros Sulawesi Selatan memiliki nilai COD, BOD dan TSS yang tinggi. Radzuan dkk. (2005) melakukan 
penelitian untuk mengetahui karakteristik lindi di TPA Air Hitam di Puchong Selangor menemukan bahwa lindi memiliki COD yang sangat rendah dan konsentrasi logam berat relatif tinggi untuk $\mathrm{Fe}, \mathrm{Zn}, \mathrm{Pb}$ dan $\mathrm{Ni}$ sedangkan $\mathrm{Mn}, \mathrm{Cd}, \mathrm{Cu}$ dan $\mathrm{Cr}$ yang ditemukan relatif rendah.

Tempat pembuangan sampah yang ada di Kota Padang adalah TPA Air Dingin. TPA Air Dingin terletak di Kelurahan Balai Gadang, Kecamatan Koto Tangah. TPA ini beroperasi sejak tahun 1989 dan memiliki luas areal 18 Ha. Pengolahan air lindi di TPA Air Dingin masih menggunakan sistem controlled landfill. Air lindi yang dihasilkan dari sampah hanya ditampung di dalam kolam dan dibiarkan mengendap untuk dialirkan menuju sungai. Kolamkolam penampungan air lindi di TPA Air Dingin juga tidak berfungsi dengan baik. Hal ini disebabkan karena di lokasi TPA sering terjadi longsor sehingga sampah masuk dan bercampur ke dalam kolam penampungan.

Penelitian di TPA Air Dingin pernah dilakukan oleh Yatim (2013) mengeni pengaruh lindi terhadap air sumur penduduk di sekitar TPA Air Dingin. Hasil dari penelitiannya adalah beberapa parameter seperti TSS, COD dan BOD telah melebihi batas baku mutu dan diketahui juga bahwa air lindi di TPA Air Dingin telah mempengaruhi kualitas air sumur penduduk sekitar. Penelitian selanjutnya juga pernah dilakukan oleh Malita dkk. (2015), tetapi hanya mengkarakterisasi mineral magnetik air lindi. Mereka menemukan bahwa air lindi di TPA Air Dingin memiliki bentuk morfologi yang sama dengan unsur yang dominan adalah $\mathrm{Fe}, \mathrm{O}$, Ti, $\mathrm{Mg}, \mathrm{C}, \mathrm{Mn}, \mathrm{Si}$ dan Al. Karena penelitian sebelumnya yang masih terbatas, maka perlu dilakukan penelitian lebih lanjut untuk mengetahui karakterisitik air lindi dan efektivitas kolam air lindi di TPA Air Dingin Kota Padang.

\section{METODE}

Lokasi yang menjadi tempat penelitian adalah TPA Air Dingin kota Padang. Sampel air lindi diambil pada 6 titik. Titik-titik pengambilan sampel ditunjukkan pada Gambar 1. A1 adalah titik di saluran sebelum masuk ke kolam, A2 dan A3 pada kolam, A4 di saluran keluar, A5 merupakan titik saat masuk sungai dan A6 adalah pada badan sungai.

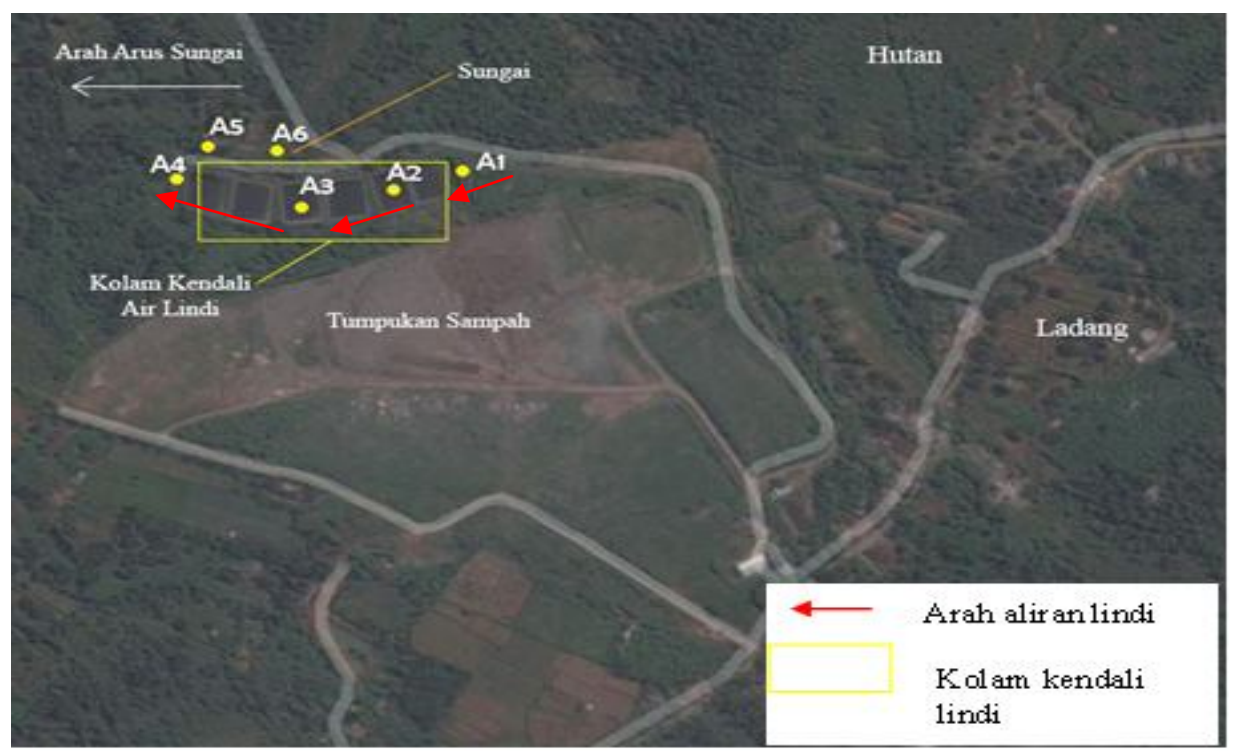

Gambar 1 Titik lokasi pengambilan sampel

\section{Pengambilan Data}

Pengukuran $\mathrm{pH}$, konduktivitas listrik dan temperatur langsung dilakukan di lokasi pengambilan sampel sedangkan pengukuran TDS, kandungan logam, COD dan BOD dilakukan di laboratorium. Pengukuran konduktivitas listrik dilakukan dengan menggunakan conductivity meter. Pengukuran $\mathrm{pH}$ dilakukan dengan mencelupkan $\mathrm{pH}$ meter ke dalam sampel dan dicatat nilai $\mathrm{pH}$ yang terbaca untuk setiap sampel. Pengukuran TDS dilakukan dengan metode gravimetry dengan langkah-langkah sebagai berikut; gelas beaker dibersihkan dan dipanaskan pada suhu $105^{\circ} \mathrm{C}$ selama 1 jam di dalam oven, kemudian didinginkan dan ditimbang dengan 
menggunakan timbangan moisture MLB-C hingga didapatkan massa gelas beaker kosong (C). Sampel diaduk hingga homogen dan kemudian disaring dengan menggunakan kertas saring whatman no. 41 sebanyak $25 \mathrm{ml}$. Sampel yang telah disaring dipanaskan menggunakan hot plate dengan suhu $250^{\circ} \mathrm{C}$ selama 1 jam hingga gelas beaker kering. Gelas beaker yang telah kering yang berisi residu dipanaskan lagi dengan oven pada suhu $105^{\circ} \mathrm{C}$ selama 1 jam agar tidak ada sisa larutan pada dinding gelas beaker. Gelas beaker yang telah dipanaskan ditimbang dengan timbangan digital dan didapatkan massa gelas beaker tambah residu (B). Kemudian, nilai TDS dapat ditentukan dengan :

$$
T D S=\frac{B-C}{V} \times 1000
$$

Pengukuran nilai COD dan BOD pada air lindi dilakukan di Laboratorium Air Teknik Lingkungan Universitas Andalas. Pengukuran COD dan BOD dilakukan untuk 6 sampel uji menggunakan metode titrasi winkler. Kadar logam berat diukur dengan Atomic Absorption Spectophotometry (AAS) di Laboratorium Air Teknik Lingkungan.

\section{HASIL DAN DISKUSI}

\subsection{Nilai Konduktivitas Listrik Air Lindi}

Tabel 1 menunjukkan nilai konduktivitas listrik di lokasi TPA Air Dingin berkisar antara $159 \mu \mathrm{S} / \mathrm{cm}$ hingga $163 \mu \mathrm{S} / \mathrm{cm}$. Nilai konduktivitas listrik pada titik A6 (air sungai) adalah $30,2 \mu \mathrm{S} / \mathrm{cm}$. Nilai konduktivitas listrik air lindi pada titik sebelum masuk ke kolam kendali (A1) atau setelah keluar dari kolam kendali A4 tidak jauh berbeda. Nilai konduktivitas listrik pada titik sampel A1 yaitu $159 \mu \mathrm{S} / \mathrm{cm}$ sedangkan pada titik A4 adalah $160 \mu \mathrm{S} / \mathrm{cm}$. Hal ini mengindikasikan bahwa air lindi sebelum dan sesudah masuk ke kolam kendali nilainya tidak jauh berbeda. Kemungkinan hal ini dapat terjadi karena kolam penampungan yang kurang berfungsi.

Tabel 1 Konduktivitas listrik, pH, TDS, temperatur, COD dan BOD di lokasi TPA Air Dingin

\begin{tabular}{|c|c|c|c|c|c|c|c|}
\hline \multirow{2}{*}{$\begin{array}{l}\text { Parameter } \\
\text { (satuan) }\end{array}$} & \multicolumn{6}{|c|}{ Sampel } & \multirow{2}{*}{$\begin{array}{c}\text { Baku mutu } \\
\text { air lindi } \\
(* / * *)\end{array}$} \\
\hline & $\mathbf{A 1}$ & $\mathbf{A 2}$ & A3 & A4 & A5 & A6 & \\
\hline Suhu $\left({ }^{\circ} \mathrm{C}\right)$ & 30,2 & 29,1 & 28,5 & 29 & 27,3 & 25,8 & $38 *$ \\
\hline $\mathrm{EC}(\mu \mathrm{S} / \mathrm{cm})$ & 159 & 163 & 159 & 160 & 159 & 30 & - \\
\hline $\mathrm{TDS}(\mathrm{mg} / \mathrm{L})$ & 1880 & 1120 & 760 & 2160 & 1160 & 400 & $2000 * *$ \\
\hline $\mathrm{pH}(-)$ & 7,4 & 7,4 & 7,5 & 7,7 & 7,6 & 8,0 & $6-9 *$ \\
\hline $\mathrm{COD}(\mathrm{mg} / \mathrm{L})$ & 345,8 & 135,1 & 387,2 & 304,3 & 215,6 & 198,3 & $300 *$ \\
\hline BOD $(\mathrm{mg} / \mathrm{L})$ & 173,6 & 63,8 & 187,2 & 152,2 & 98,5 & 87,4 & $150 *$ \\
\hline $\mathrm{Pb}(\mathrm{mg} / \mathrm{L})$ & 1,3 & 1,0 & 1,1 & 1,6 & 0,7 & 0,3 & $0,1 * *$ \\
\hline $\mathrm{Cu}(\mathrm{mg} / \mathrm{L})$ & 1,0 & 0,8 & 0,9 & 1,1 & 0,7 & 0,4 & $2,0 * *$ \\
\hline $\mathrm{Fe}(\mathrm{mg} / \mathrm{L})$ & 2,5 & 1,4 & 1,8 & 2,9 & 1,0 & 0,6 & $5,0 * *$ \\
\hline
\end{tabular}

Keterangan :

* $\quad=$ Permen LH P.59/2016 tentang baku mutu air lindi

** $\quad=$ Permen LH No.5/2014 tentang baku mutu limbah yang belum ditetapkan 


\subsection{Nilai Total Dissolved Solid (TDS) Air Lindi}

Nilai TDS keenam sampel uji bervariasi antara $760 \mathrm{mg} / 1$ hingga $2160 \mathrm{mg} / 1$ untuk sampel air lindi sedangkan sampel air sungai (A6) yang berada di sekitar TPA memiliki nilai TDS yang rendah yaitu $400 \mathrm{mg} / \mathrm{l}$ (Tabel 1). Nilai TDS pada sampel A1 yang merupakan sampel air lindi sebelum masuk ke kolam kendali adalah $1880 \mathrm{mg} / \mathrm{L}$. Nilai ini cukup tinggi tetapi masih di bawah standar baku mutu. Nilai TDS pada sampel air lindi yang telah keluar dan melalui kolam kendali (A4) melebihi nilai baku mutu yaitu $2160 \mathrm{mg} / \mathrm{L}$. Baku mutu TDS untuk air lindi adalah $2000 \mathrm{mg} / \mathrm{L}$ sesuai dengan Permen LH-5/2014 mengenai baku mutu limbah yang belum ditetapkan. Nilai TDS sampel air sungai $(400 \mathrm{mg} / \mathrm{L})$ masih di bawah ambang batas maksimum yang diperbolehkan menurut baku mutu air Kelas I PP RI Nomor 82/2001 $(\leq 1000 \mathrm{mg} / \mathrm{l})$. Dengan demikian, berdasarkan nilai TDS air sungai di sekitar lokasi TPA Air Dingin masih dapat dijadikan sumber air baku untuk air minum.

\subsection{Nilai pH Air Lindi}

Nilai pH air lindi berada di kisaran 7,4-7,7 (Tabel 1). Nilai pH air lindi sebelum masuk ke dalam kolam (A1) bernilai 7,4 dan setelah keluar dari kolam (A4) adalah 7,7. Hal ini menunjukkan bahwa $\mathrm{pH}$ air lindi di TPA Air Dingin masih berada pada rentang standar baku mutu $\mathrm{pH}(6,0-9,0)$. Walaupun berdasarkan nilai TDS air sungai di sekitar TPA masih layak untuk dijadikan sumber air baku tetapi berdasarkan nilai $\mathrm{pH}$ air sungai tersebut tidak layak karena nilai $\mathrm{pHnya}$ lebih tinggi dari baku mutu air minum $(\mathrm{pH}=7)$. Tingginya nilai $\mathrm{pH}$ diduga akibat faktor geologis dari lokasi sungai yang berada sangat dekat dengan TPA.

\subsection{Nilai Suhu Air Lindi}

Pada tiap titik pengambilan sampel terlihat penyebaran suhu yang hampir sama, yaitu suhu berkisar antara 28-29 oC. Suhu terendah teramati pada titik sampel A6 (air sungai) yaitu 25,8 oC (Tabel 1). Suhu pada titik sampel A1 cukup tinggi yaitu 30,2 oC dan pada sampel A4 yaitu 29 oC. Suhu dipengaruhi oleh faktor penyinaran sinar matahari dan proses dekomposisi yang terjadi pada tiap titik sampel. Apabila dibandingkan dengan baku mutu air limbah menurut Peraturan Pemerintah No. 5 tahun 2014, maka suhu air lindi masih di bawah baku mutu (38 $\mathrm{oC})$.

\subsection{Nilai COD Air Lindi}

Nilai COD pada titik sampel A1 cukup tinggi yaitu 345,8 mg/L. Nilai COD menurun pada sampel A2 dan naik kembali saat air lindi keluar dari kolam kendali (A4) dengan nilai $304,3 \mathrm{mg} / \mathrm{L}$ (Tabel 1). Hal ini menunjukkan bahwa bahan organik yang sukar didegradasi secara biologis lebih banyak dari pada bahan organik yang mudah terdegradasi secara biologis di TPA.

Pada titik sampel A5 (pada saat air lindi dialirkan ke sungai) nilai COD mengalami penurunan karena telah bercampur dengan air sungai. Nilai COD pada titik sampel A5 adalah 215,6 mg/L dan untuk titik A6 yaitu 198,3 mg/L. Apabila dibandingkan dengan baku mutu air lindi sesuai Permen LH P.59/2016 maka COD di TPA Air Dingin pada titik A1, A2 dan A4 telah melebihi baku mutu yaitu $300 \mathrm{mg} / \mathrm{L}$. Untuk COD air sungai (A6) nilainya masih dibawah baku mutu jika dibandingkan dengan baku mutu pada Peraturan Pemerintah No. 82, 2001. Oleh karena itu, air lindi tidak dapat dialirkan ke sungai atau badan air penerima sehingga air lindi perlu diolah terlebih dahulu sebelum dialirkan ke sungai.

\subsection{Nilai BOD Air Lindi}

Hasil pengukuran BOD untuk seluruh sampel air lindi berkisar antara 135,1 -387,2 $\mathrm{mg} / \mathrm{L}$ (Tabel 1). Nilai BOD pada titik sebelum masuk kolam penampung (A1) cukup tinggi yaitu $173,6 \mathrm{mg} / \mathrm{L}$. Nilai ini menurun setelah masuk ke dalam kolam penampungan (A4) tetapi nilainya masih tinggi yaitu dengan nilai BOD $152,2 \mathrm{mg} / \mathrm{L}$. Jika dibandingkan dengan nilai baku mutu air lindi menurut Permen LH P.59/2016 maka nilai BOD pada titik A1, A3 dan A4 telah melebihi baku mutu. Hal ini sama halnya dengan kenaikan COD. Untuk BOD air sungai (A6) nilainya masih di bawah baku mutu (Peraturan Pemerintah No. 82, 2001). 


\subsection{Kandungan Logam Berat $\mathrm{Fe}$, $\mathrm{Cu}$ dan $\mathrm{Pb}$ pada Air Lindi}

Konsentrasi kandungan $\mathrm{Fe}, \mathrm{Cu}$ dan $\mathrm{Pb}$ pada keenam sampel sangat bervariasi. Kandungan logam berat paling tinggi terdapat di sampel air lindi A4. Pada keenam sampel uji, kandungan konsentrasi mineral terbesar adalah Besi (Fe).

\subsubsection{Kandungan Logam Berat Besi ( Fe)}

Air lindi pada sampel A1 memiliki nilai kadar Fe sebesar 2,5 mg/L. Kadar Fe pada sampel A4 mengalami kenaikan dengan nilai $2,9 \mathrm{mg} / \mathrm{L}$. Begitu juga dengan sampel A5 dan A6 yang memiliki nilai kadar logam Fe yang rendah karena merupakan sampel air lindi yang telah bercampur dengan air sungai dan sampel air sungai yang berada di sekitar TPA.

Kualitas air lindi secara umum yang diteliti berdasarkan konsentrasi Fe, memiliki nilai yang lebih kecil dari baku mutu air yang ditetapkan Peraturan Menteri No. 5 tahun 2014 dan PP No.82/2001 sebesar $5 \mathrm{mg} / \mathrm{L}$. Berdasarkan nilai parameter logam berat $\mathrm{Fe}$ yang masih berada dibawah baku mutu maka kadar Fe air lindi masih belum membahayakan. Kemungkinan logam Fe berasal dari jenis sampah seperti mesin, meja, dan komponen dari bangunan.

\subsubsection{Kandungan Logam Berat Timbal $(\mathrm{Pb})$}

Tabel 1 menunjukkan bahwa keenam titik sampel mengandung logam $\mathrm{Pb}$. Kadar $\mathrm{Pb}$ paling tinggi terdapat pada sampel A4 (air lindi yang telah keluar dari kolam penampungan) dengan nilai $1,649 \mathrm{mg} / \mathrm{L}$. Kadar $\mathrm{Pb}$ paling tinggi selanjutnya adalah sampel A1 (air lindi sebelum masuk ke dalam kolam penampungan) dengan nilai $1,083 \mathrm{mg} / \mathrm{L}$. Sampel A6 yang merupakan sampel air sungai juga mengandung $\mathrm{Pb}$ dengan kadar $0,3 \mathrm{mg} / \mathrm{L}$.

Berdasarkan konsentrasi $\mathrm{Pb}$, air lindi memiliki nilai yang lebih besar dari baku mutu Peraturan Pemerintah No. 5 tahun 2014 dan PP No.82/2001 yakni sebesar 0,1 mg/L. Kadar Pb pada sampel air sungai juga telah mebihi kriteria mutu air. Kandungan $\mathrm{Pb}$ kemungkinan berasal dari jenis sampah seperti baterai, cat, dan kaleng.

\subsubsection{Kandungan Logam Berat Tembaga $(\mathrm{Cu})$}

Kadar $\mathrm{Cu}$ pada sampel air lindi sebelum memasuki kolam (A1) adalah 1,0 mg/L, sedangkan pada sampel air lindi yang telah keluar dari kolam kendali (A4) adalah 1,1 mg/L. Sampel A6 yang merupakan sampel air sungai memiliki kadar $\mathrm{Cu}$ sebesar 0,4 mg/L.

Secara umum kadar $\mathrm{Cu}$ lebih kecil dari baku mutu yang ditetapkan Peraturan Pemerintah No. 5 tahun 2014 yakni sebesar $2,0 \mathrm{mg} / \mathrm{L}$. Nilai kadar $\mathrm{Cu}$ untuk air sungai juga berada jauh di bawah baku mutu. Nilai kandungan $\mathrm{Cu}$ pada air sungai jika mengacu pada kriteria mutu air menurut PP No.82/2001 menyatakan bahwa air sungai tersebut dapat dipergunakan untuk air minum dan keperluan sehari-hari. Kandungan logam berat tembaga kemungkinan berasal dari sampah alat-alat listrik, pipa, dan kawat.

\subsection{Efektivitas Kolam Kendali Air Lindi}

Berdasarkan dari beberapa parameter yang telah diukur untuk mengetahui bagaimana karakteristik air lindi di TPA Air Dingin maka dapat diketahui bagaimana keefektifan kolam kendali air lindi. Gambar 2 memperlihatkan variasi setiap parameter untuk setiap titik sampel. Secara umum tidak ada pola tertentu tetapi nilai COD dan BOD menunjukkan pola yang hampir sama untuk setiap titik sampel. Penurunan nilai COD selalu diikuti dengan penurunan nilai BOD.

Nilai parameter yang diukur pada air lindi pada sampel A2 (kolam ke-3) selalu mengalami penurunan dari nilai air lindi sebelum masuk ke kolam kendali (A1). Namun, pada sampel A4 (setelah keluar dari kolam kendali) nilainya mengalami kenaikan kembali. Hal ini dapat disebabkan karena kolam kendali tidak berfungsi dengan baik. Kolam kendali yang ada di TPA Air Dingin telah banyak yang mengalami kebocoran dan jika musim hujan telah datang maka akan dapat menyebabkan longsor pada tumpukan sampah dan sampah akan bercampur dengan air lindi yang ada di kolam kendali. 


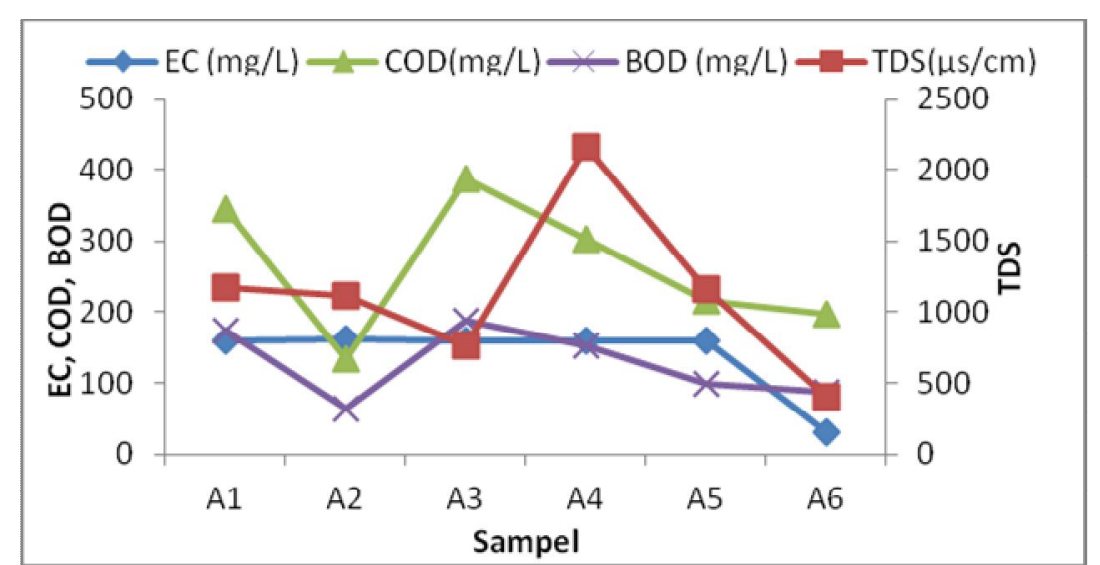

Gambar 2 Grafik nilai konduktivitas listrik, COD, BOD dan TDS

Perubahan nilai kadar logam berat $\mathrm{Pb}, \mathrm{Cu}$ dan $\mathrm{Fe}$ yang terkandung pada air lindi terhadap lokasi pengambilan titik sampel dapat dilihat pada Gambar 3. Pola penurunan kadar logam berat untuk keenam titik sampel adalah sama. Perubahan $\mathrm{Pb}$ selalu diikuti dengan perubahan $\mathrm{Cu}$ dan $\mathrm{Fe}$ begitu pula sebaliknya. Namun, masing-masing konsentrasi logam berat perubahan nilainya pada setiap titik sampel tidak beraturan.

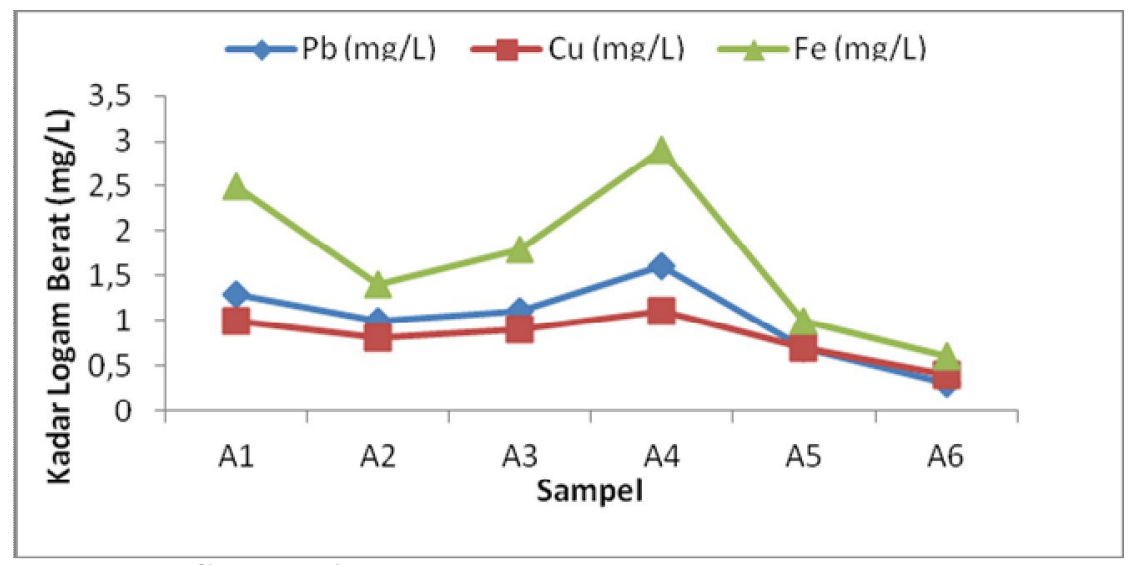

Gambar 3 Grafik kadar logam berat $\mathrm{Pb}, \mathrm{Cu}$ dan $\mathrm{Fe}$

Logam berat pada titik sampel A1 memiliki nilai yang cukup tinggi kemudian menurun pada titik sampel A2. Pada titik sampel A4 (setelah keluar dari kolam kendali) nilai kadar logam beratnya mengalami kenaikan dari titik sampel sebelumnya bahkan nilainya lebih tinggi daripada sampel A1. Hal ini menunjukkan tidak efektifnya kolam kendali air lindi di TPA Air Dingin. Penyebabnya kemungkinan karena kebocoran kolam air lindi atau longsor pada saat hari hujan sehingga menyebabkan sampah masuk ke dalam kolam kendali. Hal ini menandakan kurang efektifnya fungsi dari kolam kendali air lindi.

\section{KESIMPULAN}

Berdasarkan hasil pengukuran dari beberapa parameter yang telah dilakukan pada air lindi, diketahui bahwa air lindi pada TPA Air Dingin memiliki nilai COD dan BOD serta kandungan logam berat $\mathrm{Pb}$ yang cukup tinggi dan telah melebihi nilai baku mutu pada beberapa titik tertentu (sebelum kolam, di dalam kolam dan setelah keluar dari kolam kendali). Untuk parameter suhu dan kandungan logam berat $\mathrm{Cu}$ dan $\mathrm{Fe}$ nilainya masih berada di bawah baku mutu untuk semua titik sampel. Nilai parameter air lindi antara bak kendali berfluktuasi dan sebagian nilai lebih tinggi setelah melewati proses pada kolam kendali seperti pada parameter konduktivitas listrik, TDS, $\mathrm{pH}$ dan kandungan logam berat $\mathrm{Pb}, \mathrm{Cu}$ dan $\mathrm{Fe}$. Hal ini menunjukkan bahwa fungsi kolam kendali air lindi yang ada di TPA Air Dingin masih kurang efektif. 


\section{DAFTAR PUSTAKA}

Al-Wabel, M. I., Al Yehya, W. I., Al-Farraj, S. E., dan El-Maghraby, 2011, Characteristic of Landfill Leachates and Bio-Solids of Municipal Solid Waste (MSW) in Riyadh City Saudi Arabia, Journal of the Saudi Society of Agricultural Sciences, Vol. 10, Hal. 6570.

Damanhuri, E.,dan Tri, P., 2010, Diktat Kuliah Pengelolaan Sampah, Institut Teknologi Bandung, Bandung

Malita, Y. A., Ratnawulan, dan Mufit, F., 2015, Karakterisasi Mineral Magnerik Lindi (Leachate) TPA Air Dingin Kota Padang Menggunakan Scanning Electron Microcopie (SEM), Pillar of Physics, Vol. 5, Hal. 81-88.

Peraturan Menteri Lingkungan Hidup dan Kehutanan Republik Indonesia No.5 Tahun 2014, Baku Mutu Air Limbah bagi Usaha yang Belum Memiliki Baku Mutu Air Limbah yang Ditetapkan.

Peraturan Menteri Lingkungan Hidup dan Kehutanan Republik Indonesia No. P59/Menlhk/Setjen/Kum.1/7/2016, Baku Mutu Air Lindi bagi Usaha Tempat Pemprosesan Akhir Sampah.

Radzuan, N. Z. M., Yaacob, W. Z. W., Samsudin, A. R., Rafek, A. G., 2005, Characteristic of Leachates at the Air Hitam Sanitary Landfill in Puchong Selangor, Geological Society of Malaysia Bulletin 5, Hal. 41-46.

Susanto, P. J., Ganefati P. S., Muryani, S., dan Istiqomah, H. S., 2004, Pengolahan Lindi (Leachate) dari TPA dengan Menggunakan Sistem Koagulasi - Biofilter Anaerobic. Jurnal Tek.Ling - P3TL - BPPT Vol. 5, Hal. 167 - 173.

Yatim, E. M., dan Mukhlis, 2013, Pengaruh Lindi (Leachate) Sampah Terhadap Air Sumur Penduduk Sekitar Tempat Pembuangan Akhir (TPA) Air Dingin, Jurnal Kesehatan Mayarakat, Vol. 7, Hal. 54-59.

Zubair, A., Malamassam, M., R., Syafitri, A., T., 2015, Analisis Kualitas Air Lindi TPA Tamangapa Dan Pengaruhnya Terhadap Lingkungan, Jurnal Teknik Sipil Universitas Hasanuddin Makasar, Hal.4-5. 